\title{
5.5 Method of assesing the financial stability of the enterprise
}

Stability in modern scientific and reference sources is mostly interpreted as the ability of a system to keep certain properties and characteristics unchanged or almost unchanged, or as the ability of the system to restore the previous (or close to) state after some disturbance, which is manifested in deviation of system parameters from nominal value. In a broader sense, this term means the ability of a system to perform its functions despite the influence of endogenous and exogenous factors [267]. If we apply this term to financial activities, then in the most generalized form, financial stability can be interpreted as the ability to maintain/restore the desired (target) parameters of the financial condition. However, in modern research there is no single interpretation of this concept, which sometimes leads to misunderstandings, variability in the identification of its parameters, and, accordingly, the ambiguity of approaches. O. Pavlovskaya, N. Prytulyak and N. Nevmerzhytska consider financial stability from the standpoint of the company's ability to provide inventories and expenses at its own expense, to prevent unjustified receivables and payables and to settle liabilities on time [268, p.189]. In our opinion, the presented approach is somewhat narrow and considers only the so-called current financial stability. However, this is not enough to ensure the sustainable development of the enterprise, which is achieved by long-term capital investment and compliance with certain proportions between the types of long-term capital. G. Kramarenko understands financial stability as a financial and economic condition of the enterprise, in which solvency maintains a tendency to stability, i.e., it is constant over time, and the ratio of equity and debt capital is within the limits that ensure this solvency [269]. In fact, the author identifies the concepts of solvency and financial stability. M. Bilyk believes that financial stability is a state of financial resources of the enterprise, in which the rational disposal of them is a guarantee of own funds availability, stable profitability, and ensuring the process of expanded reproduction [270, p.302].

Based on the etymology of the concept of "sustainability" and the generalization and development of existing scientific approaches, the financial stability of the 
enterprise can be considered as the ability to restore and maintain target volumes and proportions of financial resources, which allows the company to maintain a stable financial position over time: to avoid excessive financial risks, to maintain a sufficient level of self-financing, to avoid bankruptcy, to form financial support for the development of operating activities, to compensate for the negative environmental factors impact. Thus, we can identify the main parameters of financial stability (figure 5.5.1).

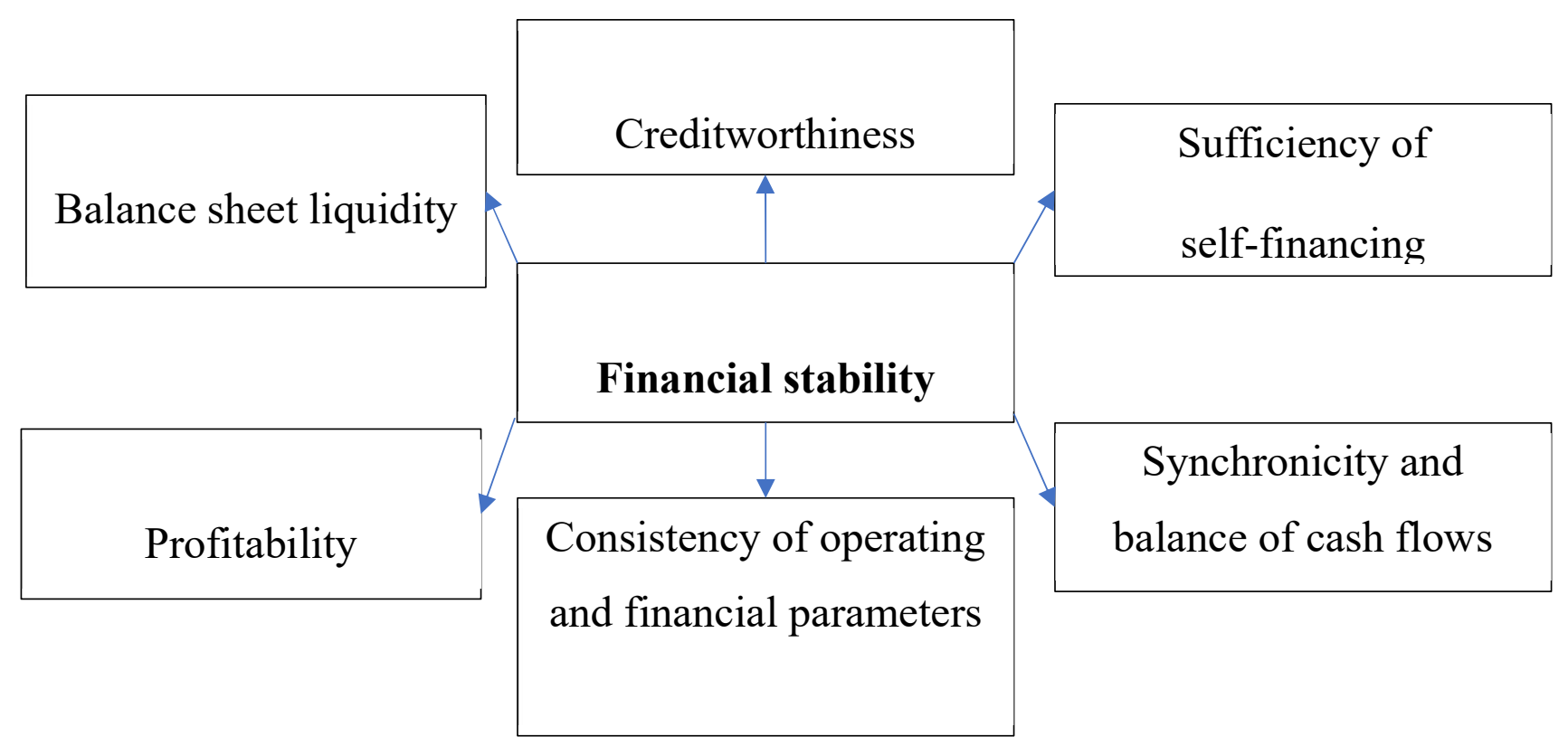

Figure 5.5.1. Parameters of financial stability of the enterprise Source: compiled by the authors for [267-272]

Based on the parameters of financial stability, it can be understood that the assessment and management should be carried out on all control circuits in accordance with the defined tasks with the choice of special diagnostic methods (Table 5.5.1). 
Table 5.5.1

Management system of financial stability of the enterprise

\begin{tabular}{|c|c|c|c|}
\hline \multirow{2}{*}{ Subsystems } & \multicolumn{3}{|c|}{ Management contour } \\
\hline & Operational & Current & Strategic \\
\hline 1 & 2 & 3 & 4 \\
\hline Task & $\begin{array}{l}\text { Ensure } \\
\text { synchronicity of } \\
\text { cash flows, } \\
\text { sufficient } \\
\text { liquidity and net } \\
\text { working capital }\end{array}$ & $\begin{array}{ll}\text { Ensure balanced cash } \\
\text { flows, sufficient } & \text { self- } \\
\text { financing } & \text { and } \\
\text { creditworthiness } & \end{array}$ & $\begin{array}{l}\text { Ensure a sufficient } \\
\text { level of self- } \\
\text { financing } \\
\text { investment } \\
\text { activities and } \\
\text { compliance with a } \\
\text { sustainable growth } \\
\text { rate }\end{array}$ \\
\hline $\begin{array}{l}\text { Methods } \\
\text { analysis }\end{array}$ & $\begin{array}{l}\text { - coefficient; } \\
\text { - balance; } \\
\text { - statistical. }\end{array}$ & $\begin{array}{l}\text { - coefficient; } \\
\text { - discriminant analysis. }\end{array}$ & $\begin{array}{l}\text { - methods of } \\
\text { integrated analysis. }\end{array}$ \\
\hline $\begin{array}{l}\text { Principles of } \\
\text { management }\end{array}$ & \multicolumn{3}{|c|}{$\begin{array}{l}\text { Target orientation; integration into the financial decision-making } \\
\text { system; dynamism; responsibility; scientific validity }\end{array}$} \\
\hline $\begin{array}{l}\text { Information } \\
\text { support }\end{array}$ & \multicolumn{3}{|c|}{$\begin{array}{l}\text { External: information on the state of the financial market, } \\
\text { macroeconomic parameters, information on the state and working } \\
\text { conditions of the main counterparties in financial activities; } \\
\text { Internal: financial report; management reporting; analytical } \\
\text { accounting data; forecast of financial activity of the enterprise. }\end{array}$} \\
\hline
\end{tabular}

Source: developed by the authors

In the available research, the vast majority of proposals for assessing financial stability are reduced to recommendations for the application of the coefficient method and balance sheet models. Among the main ratios, it is proposed to use liquidity ratios, capital structure ratios and the current asset provision with net working capital. Among the balance sheet methods, it is proposed to apply the identification model of financial 
stability type by sources of financing stocks; various analytical balances, etc. Namely, we can say that the vast majority of methods for assessing financial stability: 1) is limited to the analysis of the balance sheet, i.e., it is static. Balance sheet data are instantaneous and therefore do not always objectively reflect the level of financial stability, especially characteristics such as absolute liquidity. Of course, the study of balance ratios in the dynamics partially solve this problem. However, often such an analysis is purely retrospective in nature, allows you to identify trends and their causes, taking this into account when planning financial, investment and operating activities. However, such an analysis has questionable analytical value for making operational financial decisions; 2) mainly focused on the current management contour and do not take into account the needs of operational and strategic levels of government.

Based on this, it becomes clear the need to improve existing approaches to assessing financial stability, expanding the use of analytical tools and structuring the evaluation process in accordance with the management contours with the choice of appropriate analytical methods and tools (Figure 5.5.2).

Operational management contour

Stage 1. Assessing the level of synchronicity of the enterprise cash flows

Stage 2. Assessing the adequacy of the average cash reserve

Stage 3. Estimation of the level of the enterprise net working capital

\section{Current management contour}

Stage 4. Estimation of current liquidity ratios dynamics and level of working capital

Stage 5. Estimation of the current financial stability type by sources of stock financing

Stage 6. Assessing the level of the enterprise cash flow balance

Stage 7. Estimation of the enterprise capital structure

Stage 8 . Assessing the enterprise debt capacity 
Strategic management contour

Stage 9. Estimation of growth stability

Stage 10. Assessing the adequacy of reinvestment of net cash flow from operating activities

Stage 11. Forecast assessment of prospects for the development of the proportions of financial resources of the enterprise

Figure 5.5.2. Structural and logical sequence of assessing the enterprise financial stability

Source: developed by the authors

Thus, within the operational management contour, the emphasis is on assessing the enterprise operational solvency on static and dynamic indicators. Thus, at the first stage, the level of uniformity and synchronicity of cash flows according to analytical accounting data, or operational management reports on cash flows is investigated.

In the process of such analysis, standard statistical tools are used: standard deviations, coefficients of incoming and outgoing cash flows variation, the correlation coefficient between incoming and outgoing cash flow are calculated. Also, the facts of deferred spending (deferred payments) are investigated and recorded, which presence is an indicator of payments inconsistency over time. The reasons for payments transfers are determined in order to identify technical cash gaps, or deeper causes of cash shortages.

The second stage estimates the share of monetary assets in the structure of current assets, their ratio to the volume of current liabilities. In combination with dynamic indicators, this enables to assess the level of funds adequacy in the accounts better, change the policy of their planning, identify opportunities for coordination of payments. 
In the third stage, the amount of net working capital is identified. Its absence imposes stricter requirements for cash flow planning and payment discipline control. Its presence indicates a certain "airbag" in ensuring financial stability.

The results of operational analysis are significantly deepened within the current assessment. Thus, at the fourth stage, the dynamics of the total, intermediate coverage coefficients the level of net working capital is studied.

The fifth step identifies the type of current financial stability depending on the sources of stock funding. Since inventories are the least liquid part of current assets, they must be covered by so-called normal sources of financing, which include net working capital, current accounts payable for goods, works and services and bank loans used to finance inventories. An unstable or critical financial situation indicates problems in ensuring current financial stability, which require finding reserves for net working capital growth.

At the sixth stage, the level of cash flow balance is studied, that is, dynamic indicators are evaluated. Within the framework of such analysis, the cash flow coefficients from operating activities, the level of cash flow efficiency, the quality level of net cash flow from operating activities, the cash flows liquidity ratio are assessed. The insufficient level of these indicators indicates disparities in operating activities, in the formation of credit policy and the policy of attracting commodity credit. First of all, it requires finding ways to optimize operating costs, increase revenue.

At the seventh stage, the main indicators of capital structure are evaluated: the financial stability coefficient, financial leverage, debt, equity maneuverability. Based on the results of such an analysis, decisions can be made to change the target capital structure and ways to ensure it.

At the eighth stage, the debt capacity of the enterprise is assessed. To assess it, the ratio of interest on the loan due to EBIT, the ratio of interest on the loan and shortterm loans due to net cash flow from operating activities are calculated. These indicators are important markers of the enterprise creditworthiness. 
Within the strategic management contour, the parameters of sustainable growth, the ability to finance investment programs and prospects for improving or maintaining the proportions of financial resources are studied.

Thus, the ninth stage evaluates the company's compliance with sustainable growth, that is, the actual growth rate of activity is compared with a stable one, which is determined by multiplying the return level on equity by the capitalization ratio of net profit. Exceeding the actual growth rate of net revenue over stable indicates the inconsistency of the financial parameters of the enterprise tasks and operating activities rates. Such a disparity often leads to the bankruptcy of profitable growing enterprises. Its identification requires a review of functional financial policies in order to avoid a shortage of financial resources.

Therefore, at the tenth stage, such important indicators as the net profit capitalization ratio and the net cash flow reinvestment ratio are analyzed. The low capitalization ratio of net income indicates large volumes of net profit consumption, which in combination with the active growth of operating activities and investment often causes a shortage of resources. A similar analytical function is performed by the reinvestment ratio of net cash flow from operating activities, which is estimated for a period of 3-5 years.

At the eleventh stage, the prospects for improving or maintaining the proportions of financial resources in the future are assessed. This analysis is based on the enterprise forecasts and the macro environment development, financial market and legislation using SWOT-analysis and involves assessing the threats and opportunities generated by environmental factors and identifying strengths and weaknesses of the enterprise (its internal environment). The result of such an analysis is a revision of existing financial policies and their adjustment in the process of developing a financial strategy. 